\title{
Pendampingan Remaja Dalam Meningkatkan Pengetahuan Dan Sikap Pencegahan HIV/AIDS Di Daerah Pesisir Kabupaten Sumenep
}

\author{
Hadina Eka Camalia ${ }^{1 *}$, Dian Permatasari ${ }^{2}$, Emdat Suprayitno $^{3}$, Sri Yunita \\ Suraida Salat ${ }^{4}$ \\ ${ }^{1,2,3,4}$ Fakultas Ilmu Kesehatan Universitas Wiraraja \\ *Email: hadina@gmail.com
}

\begin{abstract}
Background: Human Immunodeficiency Virus (HIV) or Acquired Immunodeficiency Syndrome (AIDS) is a growing health problem in Indonesia. From 1987 to 2019, there were 102,667 AIDS sufferers. Adolescents aged 15-24 years are a group that is vulnerable to HIV. The purpose of PKM is for universities to play a role in developing public knowledge about reproductive health and the spread of HIV/AIDS among adolescents infection. Adolescents are a group that is more likely to transmit HIV/AIDS because they are vulnerable to risky behavior problems, such as premarital sex and substance abuse. Methods: The target of service is youth in coastal areas. Problems are solved in three stages of activity, namely preparation, implementation and evaluation. Preparation is done by conducting a preliminary survey to see conditions in the field. The implementation is carried out by training, using the lecture method, namely the presentation technique, followed by question and answer discussions and exercises as a form of PKM activities. Evaluation of activities is carried out for each stage by collecting and concluding data from each stage of activity. Results: Before distributing 24 questionnaires containing information about adolescent reproductive function and HIV/AIDS to counseling participants, the result was $65 \%$. Meanwhile, from the results of a survey of all participants to assess expansion achievement, it was found that $84 \%$. A significant increase in participants' knowledge was $18 \%$. Conclusion: By providing knowledge to parents, we can reach youth to avoid problems related to HIV/AIDS.
\end{abstract}

Keywords: HIV, AIDS, knowledge, attitude;

\section{PENDAHULUAN}

Dinas Kesehatan Bali, Komisi Penanggulangan AIDS Bali (KPA) dan pemangku kepentingan terkait termasuk LSM lokal melaksanakan berbagai strategi. Strategi yang telah dilakukan antara lain pendidikan kesehatan, distribusi kondom, tes IMS dan pengobatan, serta penggunaan strategis antiretroviral (Suharto et al., 2020).

Pelaksanaan strategi yang dilakukan terbatas karena tidak ditujukan kepada kelompok lain yang berhubungan langsung ke kelompok PSP, yaitu pelanggan mereka. Kelompok ini dikenal sebagai lelaki berisiko tinggi dan memiliki peran penting pada penularan HIV ke populasi umum, menghubungkan tingginya prevalensi infeksi HIV di antara PSP untuk wanita pada populasi umum wanita antara lain istri atau pacarnya. Kelompok ini diberi label sebagai manusia bergerak dengan uang (3M) sehingga dalam sejumlah survei, pelanggan pekerja seks atau lelaki berisiko tinggi ini diwakili sebagian besar oleh sopir (truk atau taksi) dan buruh bangunan yang dating dari luar (Kusnan \& Eso, 2021).

Rendahnya penggunaan kondom secara konsisten dan tingginya jumlah klien merupakan beberapa faktor yang menyebabkan PSP rentan terhadap infeksi HIV. Pada tahun 2015, terdapat 36,9 juta orang yang hidup dengan HIV/AIDS di seluruh dunia.

Pada tahun 2012, terdapat sekitar 2,3 juta infeksi baru, dengan kejadian 2 juta (Yogani et al., 2015). Ini adalah penurunan 35\% dibandingkan dengan kejadian pada tahun 2000. Sebagian besar penularan HIV di Asia terjadi melalui heteroseksualitas dan masih terkonsentrasi pada perilaku berisiko tinggi. Jumlah Orang Terinfeksi HIV/AIDS (ODHA) (Limasale et al., 2017). 
Ada sekitar 591.823 orang di Indonesia, di antaranya 10.616 adalah wanita pekerja seks langsung (WPSL) dan 98.443 klien adalah 4.444 kota. Ada 4,1 ODHA WPSL dan 26,6\% ODHA pelanggan dan mitra tetap (Wulandari et al., 2018).

Untuk mengurangi risiko penularan HIV di kalangan WPS di Provinsi Bali, sejak tahun 2009. Salah satu penyebab rendahnya pemakaian kondom adalah negosiasi oleh WPS kepada pelanggannya. Kesadaran pelanggan untuk menggunakan kondom akan sangat dipengaruhi oleh pengetahuan pelanggan terhadap HIV/AIDS (Wulandari et al., 2018).

Untuk itu perlu dilakukan suatu upaya untuk meningkatkan pengetahua pelanggan tentang HIV/AIDS yang bisa dilakukan melalui kegiatan penyuluhan. Pendidikan kesehatan atau health education adalah upaya membujuk atau mendidik suatu masyarakat bahwa masyarakat bersedia melakukan tindakan untuk memelihara dan meningkatkan kesehatannya (Permatasari \& Suprayitno, 2021).

\section{TINJAUAN PUSTAKA}

HIV merupakan virus dimana kekekebalan tubuh manusia yang diserang. AIDS adalah singkatan dari Acquired Immunodeficiency Syndrome. Diperoleh berarti diperoleh, bukan turun temurun. Imunitas berhubungan dengan sistem imun kita. Deficiency artinya kekurangan. Sindrom atau sindrom mengacu pada penyakit yang memiliki serangkaian gejala daripada gejala tertentu. Jadi, AIDS mengacu pada sekumpulan gejala yang disebabkan oleh defisiensi atau melemahnya sistem kekebalan tubuh yang terbentuk setelah kita lahir (Susanti, 2019).

Virus HIV/AIDS melalui perantara darah manusia sehingga dapat masuk ke dalam tubuh, air mani, dan cairan alat vital. Setelah masuk ke dalam tubuh, limfosit CD4 menjadi target utama virus ini karena virus memiliki afinitas terhadap molekul CD4 permukaan. Virus menjadikan informasi genetik dalam bentuk yang terintegrasi ke dalam informasi genetik sel yang diserangnya. Dengan kata lain, ia menggunakan reverse transcriptase untuk mengubah bentuk RNA (asam ribonukleat) menjadi DNA (asam deoksiribonukleat) (Damayanti et al., 2019).

\section{DESAIN PENELITIAN}

Metode yang dilakukan dalam PKM ini yaitu Observasi ke Desa Bangkal. Identifikasi permasalahan mitra, penentuan solusi, koordinasi dengan kepala sekolah. Pelaksanaan kegiatan penyuluhan HIV/AIDS. Dengan metode ceramah dan pembagian leaflet.

Kegiatan penyuluhan HIV/AIDS diikuti oleh remaja di Desa Bangkal yaitu sebanyak 54 orang yang terdiri dari remaja laki-laki dan perempuan yang dilaksanakan di ruang balai Desa Bangkal. Evaluasi kegiatan remaja desa Bangkal sangat antusias dan aparat desa Bangkal juga sangat mendukung dan kooperatif dalam kegiatan PKM ini. Penilaian akhir dilaksanakan dengan mengadakan post-test terkait materi yang telah disampaikan.

Setelah kegiatan selesai kemudaian dilakukan pemberian leaflet. Leaflet diberikan kepada pihak kepala Desa sebagai koleksi bahan bacaan di Desa menghadapi pertanyaan remaja disana. Leaflet berisi materi tentang HIV/AIDS

\section{HASIL PENELITIAN}

Penyuluhan HIV/AIDS mempunyai tujuan menyampaikan pengetahuan HIV/AIDS dengan menggunakan media audio dan visual. Tujuan menggunakan Media 
ini dalam penyuluhan HIV/AIDS di Desa Bangkal, Kabupaten Sumenep yaitu agar materi HIV/AIDS dapat dengan mudah dimengerti oleh remaja. Dengan bantuan media audiovisual sangat membantu dalam penyampaian materi. Penyuluhan menggunakan metode ceramah dan dilengkapi dengan leaflet memudahkan remaja dalam pemahaman materi yang disampaikan. Materi penyuluhan mencakup HIV/AIDS khususnya tentang pengertian, cara penularan gejala dan pencegahan pada penyakit HIV/AIDS.

Hasil evaluasi yaitu seluruh remaja meningkat pemahamannya. remaja juga mempunyai kesempatan untuk menanyakan materi yang disampaikan pada saat penyuluhan. Cukup banyak pertanyaan yang diajukan remaja tentang materi penyuluhan. Hasil ini sesuai dengan penelitan Harmawati 2018 dimana pendidikan kesehatan meningkatkan pemahaman dan pengetahuan pelajar SMA pada HIV/AIDS (Harmawati et al., 2018).

Setelah dilakukan tanya jawab dapat didapatkan meningkatnya pengetahuan remaja mengenai pengertian dan cara penularan HIV/AIDS. Semua materi penyuluhan dapat tersampaikan secara baik dan lancar tanpa hambatan apapun. Ketercapaian dan keberhasilan dari kegiatan pengabdian kepada masyarakat ini yaitu meningkatnya pengetahuan remaja tentang HIV/AIDS terlihat dengan adanya feedback dari remaja dan pada waktu ditanyakan merekan bisa menjawab tentang hasil penyuluhan tersebut.

Hasil dari PKM ini yaitu Sebelum dilakukan PKM permasalahan mitra yaitu kurangnya pengetahuan tentang pengertian,gejala,cara penularan,da pencegahan HIV/AIDS, dan setelah dilakukan PKM ini masyarakat desa pesisir adanya peningkatan pengetahuan remaja tentang HIV/AIDS.

\section{PEMBAHASAN}

Kegiatan pengabdian pendampingan remaja dalam meningkatkan pengetahuan dan sikap pencegahan HIV/AIDS di Daerah Pesisir dapat berjalan dengan lancar. Pelatihan remaja. Kebanyakan peserta mengeluhkan kurangnya pengetahuan dan pemahaman pengetahuan dan sikap pencegahan HIV/AIDS. Remaja bertanggungjawab atas kegiatan pembelajaran yang dilaksanakannya sehingga mereka harus menjaga kualitas pembelajarannya. Pelatihan ini memberikan manfaat bagi remaja untuk meningkatkkan pengetahuan dan sikap. Hal ini akan berdampak pada peningkatan penguasaan pengetahuan dan keterampilannya sebagai remaja yang cerdas.

Evaluasi Kepala desa dan perangkat desa dapat bekerjasama dan bekerjasama dengan baik yang dibuktikan dengan persiapan kegiatan dengan ikut serta dalam penyiapan atau pendirian tempat pendidikan kesehatan. Pelaksanaan pendidikan kesehatan dilaksanakan secara aktif oleh pemuda di desa Bangkal (desa pesisir), pemuda berpartisipasi aktif dalam diskusi HIV/AIDS. Peserta kegiatan dapat memahami HIV/AIDS dan menjelaskan apa yang telah ditularkan. Evaluasi hasil Peserta kegiatan dapat memahami dan memahami pentingnya mengetahui tentang HIV/AIDS serta gejala dan pencegahannya.

Daya Tahan Bagi remaja, perlu ditingkatkan pemahaman tentang kesehatan, khususnya masalah yang sering dihadapi remaja dan masyarakat, agar mendapat manfaat. Partisipasi mitra dalam kegiatan TIG cukup aktif, terbukti sejak awal kerja sosialisasi kepala desa dapat berjalan lancar. Kegiatan penyuluhan pertanian dilaksanakan di balai kota desa Pasongsongan (desa pesisir) Sumenep dengan penyiapan kendaraan operasional yang dapat langsung didukung oleh gotong royong. Dalam pelaksanaan pemekaran, peran mitra sangat menguntungkan bila mitra aktif adalah pemuda dari desa Pasongsongan (desa pesisir) sehingga dalam kegiatan ini mitra 
operasi secara langsung mempengaruhi masyarakat. agar acara dapat berjalan dengan lancar.

Berdasarkan hasil kegiatan penyuluhan kesehatan tentang "HIV / AIDS" berdampak baik khususnya bagi remaja dapat meningkatkan pengetahuannya dalam pencegahan penyebaran HIV / AIDS

\section{KESIMPULAN DAN SARAN}

Kegiatan Penyuluhan HIV/AIDS di Desa Bangkal menambah wawasan pengetahuan remaja tentang pengertian, cara penularan, gejala dan pencegahan HIV/AIDS. Kegiatan pengabdian kepada masyarakat tentang pengertian, cara penularan, gejala dan pencegahan HIV/AIDS berjalan dengan lancar, dan remaja sangat antusias dalam kegiatan tersebut.

\section{UCAPAN TERIMA KASIH}

Terimakasih kepada Kepala Desa Bangkal Kecamatan Kota Sumenep Kab Sumenep yang telah memberikan ijin dalam kegiatan ini.

\section{DAFTAR RUJUKAN}

Damayanti, A., Tyastuti, S., \& Yulianti Sari, R. (2019). Pengaruh Media Video Terhadap Peningkatan Pengetahuan HIV/AIDS Pada Remaja di SMKN 1 Temon. Poltekkes Kemenkes Yogyakarta.

Harmawati, H., Sari, D. A., \& Verini, D. (2018). Pengaruh Pendidikan Kesehatan Terhadap Tingkat Pengetahuan Pelajar SMA Tentang HIV/AIDS. Jurnal Endurance: Kajian Ilmiah Problema Kesehatan, 3(3), 588-595.

Kusnan, A., \& Eso, A. (2021). PELATIHAN DAN PENYULUHAN HIV/AIDS PADA LELAKI BERISIKO TINGGI DI KOTA KENDARI. JURNAL PARADIGMA (PEMBERDAYAAN \& PENGABDIAN KEPADA MASYARAKAT), 3(2), 17-22.

Limasale, Y. H., Istiarti, V. G. T., \& Musthofa, S. B. (2017). Faktor-Faktor Yang Berhubungan Dengan Praktik Penggunaan Kondom Dan Pelicin Pada Kelompok Gay Dalam Upaya Pencegahan Hiv/Aids Di Kota Semarang. Jurnal Kesehatan Masyarakat (Undip), 5(5), 1132-1138.

Permatasari, D., \& Suprayitno, E. (2021). Pendidikan Kesehatan Reproduksi pada Remaja. Jurnal Empathy Pengabdian Kepada Masyarakat, 1-5.

Suharto, S., Gurning, F. P., Pratama, M. Y., \& Suprayitno, E. (2020). Implementasi Kebijakan Penanggulangan HIV/AIDS di Puskesmas Teladan. Jurnal Riset Hesti Medan Akper Kesdam I/BB Medan, 4(2), 131-136.

Susanti, R. W. D. (2019). Gambaran Pengetahuan Mahasiswa Tentang HIV/AIDS Di Universitas Pasir Pengaraian Kabupaten Rokan Hulu. Jurnal Martenity and Neonatal, 2(6), 341-349.

Wulandari, L. P. L., Kaldor, J., \& Januraga, P. P. (2018). High condom use but low HIV testing uptake reported by men who purchase sex in Bali, Indonesia. Aids Care, 
$30(10), 1215-1222$.

Yogani, I., Karyadi, T. H., Uyainah, A., \& Koesnoe, S. (2015). Faktor-faktor yang Berhubungan dengan kenaikan CD4 pada pasien HIV yang mendapat highly active antiretroviral therapy dalam 6 bulan pertama. Jurnal Penyakit Dalam Indonesia, 2(4), 217-222.

Dinas Kesehatan Kabupaten Sumenep, Laporan situasi perkembangan HIV AIDS di Kabupaten Sumenep, Kabupaten Sumenep, 2018.

Kemenkes RI, Laporan Situasi Perkembangan HIV AIDS di Indonesia Trimester II. Ditjen PP\&PL. Jakarta, 2012.

Green, Laurence. W. dan Marshall W. Kreuter. Health Promotion Planning And Educational and Environmental Approach. USA: Mayfield Publishing Company : California, 2000

Irwanto, Pedoman dan Modul Pencegahan Positif. Pusat Penelitian HIV/AIDS Unika Atma Jaya. Jakarta, 2012.

KPAN, Informasi Dasar HIV AIDS. tersediadalam:

http://www.aidsina.org/modules.php?name=FAQ\&myfaq=yes\&id_cat=1\&categor ies=HI V-AIDS . Jakarta, 2012. di akses tanggal 01-12-19.

Depkes RI, Pedoman Pelayanan Konseling dan Testing HIV/AIDS secara Sukarela (Voluntary Counselling and Testing). Jakarta, 2006. 